\title{
Analisis Bencana Longsor Lahan di Kabupaten Tuban Melalui Pengolahan Citra Satelit Multilevel Untuk Pembuatan Peta Potensi Longsor
}

\author{
Citra Prastika dan Bangun Muljo Sukojo \\ Departemen Teknik Geomatika, Fakultas Teknik Sipil dan Perencanaan, Institut Teknologi Sepuluh \\ Nopember (ITS) \\ e-mail: bangunms@gmail.com
}

\begin{abstract}
Abstrak-Longsor merupakan salah satu jenis gerakan massa tanah atau batuan, ataupun percampuran keduanya, menuruni atau keluar lereng akibat dari terganggunya kestabilan tanah atau batuan penyusun lereng tersebut. Efek tanah longsor terhadap manusia dan bangunan dapat dikurangi dengan cara menghindari daerah rawan, menyiarkan larangan, atau dengan menerapkan standar keselamatan saat berada di daerah tersebut. Oleh karena itu, tujuan dalam studi ini yaitu untuk mengetahui potensi/risiko longsor yang berperan dalam mitigasi bencana longsor di Kabupaten Tuban. Daerah rawan bencana longsor dapat diidentifikasi dengan menggunakan data penginderaan jauh dan sistem informasi geografis. Pada penelitian ini dilakukan pembuatan peta daerah rawan bencana longsor dengan menggunakan beberapa parameter penyebab tanah longsor diantaranya curah hujan, jenis tanah, kemiringan lereng, dan tutupan lahan. Parameter tersebut akan diolah dan dianalisis serta akan diperkuat dengan menggunakan data penginderaan jauh yakni citra satelit resolusi menengah Landsat 8, citra satelit resolusi tinggi SPOT dan citra satelit resolusi sangat tinggi Quickbird. Hasil yang didapatkan berupa peta kerawanan longsor yang terbagi dalam 5 kelas kerawanan yakni kerawanan sangat rendah, kerawanan rendah, kerawanan sedang, kerawanan tinggi, dan kerawanan sangat tinggi yang menempatkan Kabupaten Tuban didominasi oleh tingkat kerawanan sedang dengan luas $\mathbf{9 9 . 5 1 9 , 9}$ ha, sedangkan untuk tingkat kerawanan sangat tinggi hanya seluas 268,537 ha.
\end{abstract}

Kata Kunci-Kabupaten Tuban, Penginderaan Jauh, Satelit Landsat 8, Satelit SPOT, Satelit Quickbird, Sistem Informasi Geografis, Tanah Longsor.

\section{PENDAHULUAN}

B ENCANA hidro-meteorologi seringkali melanda Indonesia dikarenakan memiliki curah hujan yang tinggi dan beriklim topis. Banjir dan kekeringan merupakan bencana hidro-meteorologi yang dapat memicu adanya bencana alam lain. Badan Nasional Penanggulangan Bencana mencatat dari total bencana meteorologi yang paling sering terjadi di Indonesia adalah bencana banjir diikuti oleh longsor.

Tuban merupakan salah satu wilayah yang merasakan dampak berupa kerugian yang disebabkan oleh bencana longsor. Strategi dan upaya penanggulangan bencana tanah

longsor diperlukan sebagai langkah awal dalam mitigasi bencana longsor, salah satunya adalah dengan memasyarakatkan daerah rawan longsor melalui pembuatan peta potensi longsor.

Bahaya tanah longsor dapat diidentifikasi melalui sistem informasi geografis dan penginderaan jauh. Dengan melakukan pengolahan terhadap parameter penyebab longsor seperti curah hujan, jenis tanah, kemiringan lereng, dan tutupan lahan, nantinya akan diperkuat dengan menggunakan data penginderaan jauh yakni citra satelit multilevel. Parameter longsor beserta data pendukungnya diolah dan dianalisis menggunakan teknologi berbasis Penginderaan Jauh dan Sistem Informasi Geografis.

Penelitian ini dilakukan dengan tujuan untuk mengetahui wilayah yang berpotensi longsor, serta parameter yang mempengaruhi terjadinya longsor lahan di Kabupaten Tuban dengan luaran dalam bentuk peta potensi longsor dimana dalam penyusunannya mengacu pada beberapa aturan pembuatan peta potensi longsor. Dalam penyelesaiannya, penelitian ini diharapkan dapat memberikan informasi kepada pemerintah dan masyarakat mengenai wilayah yang memiliki potensi longsor di Kabupaten Tuban, khususnya kepada masyarakat yang berada di sekitar wilayah yang berpotensi longsor.

\section{METODOLOGI PENELITIAN}

\section{A. Lokasi Penelitian}

Lokasi penelitian ini berada pada Kabupaten Tuban dengan luas wilayah sekitar 183.994.562 Ha. Letak astronomi Kabupaten Tuban pada koordinat $111^{\circ} 30^{\prime}-112^{\circ}$ $35 \mathrm{BT}$ dan $6^{\circ} 40^{\prime}-7^{\circ} 18^{\prime} \mathrm{LS}$.

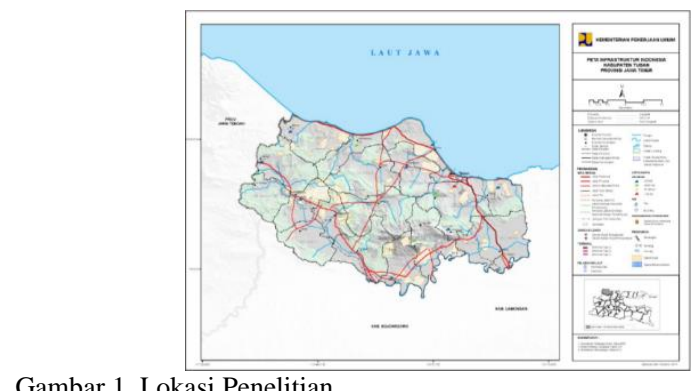

Gambar 1. Lokasi Penelitian

(Sumber: Dinas Pekerjaan Umum Tuban)

B. Data dan Peralatan

1) Data

Data yang digunakan dalam penelitian ini adalah: 
1. Data tabular curah hujan Kabupaten Tuban tahun 2015 (sumber: Dinas Pekerjaan Umum Tuban).

2. Data DEM Satelit Astrium Terra SAR $X$ Kabupaten Tuban tahun 2012 (sumber: Bappeda Tuban).

3. Data jenis tanah Kabupaten Tuban tahun 2008 (sumber: Bappeda Tuban).

4. Data kemiringan lereng Kabupaten Tuban tahun 2008 (sumber: Bappeda Tuban).

5. Citra resolusi menengah Landsat Path 119 Row 65 tanggal 13 Oktober 2015 (sumber: http://earthexplorer.usgs.gov).

6. Citra satelit resolusi tinggi SPOT 6/7 Tahun 2015-2017 (sumber: LAPAN).

7. Citra resolusi sangat tinggi Quickbird tahun 2013 (sumber: Bappeda Tuban).

8. Batas administrasi (sumber: Peta RBI 1:25.000).

9. Data Citra Foto.

10. Data GPS.

\section{2) Peralatan}

Perlatan yang digunakan pada penelitian ini meliputi:

a. Perangkat Keras
i. GPS Geodetic dual frequency.
ii. Phantom 3 Advance.
iii. Laptop.

b. Perangkat Lunak

i. Perangkat lunak pengolah data geospasial.

ii. Perangkat lunak pengolah data citra satelit.

iii. Perangkat lunak pengolah data GPS.

iv. Perangkat lunak pengolah orthorektifikasi.

v. Perangkat lunak pengolah data statistic.

\section{Tahapan Pengolahan Data}

Tahapan pengolahan data pada penelitian ini adalah sebagai berikut:

1. Pembuatan Peta Curah Hujan

Melakukan interpolasi pada data curah hujan kemudian

klasifikasi dan pemberian skor pada hasil interpolasi tersebut.

2. Pembuatan Peta Jenis Tanah

Melakukan klasifikasi dan pemberian skor pada data yang tersedia.

3. Pembuatan Kemiringan Lereng

Melakukan klasifikasi dan skoring pada data yang tersedia.

4. Pembuatan Peta Tutupan Lahan

Melakukan koreksi radiometrik dan klasifikasi digital pada citra Landsat 8 serta menghitung matriks konfusi dari hasil klasifikasi dan melakukan pemberian skor.

5. Overlay, skoring, dan reklasifikasi

Melakukan overlay dan skoring pada seluruh parameter. Skoring yang digunakan dalam penelitian ini mengacu pada beberapa referensi dari penelitian serupa seperti yang ditunjukkan pada tabel berikut.

Tabel 1.

Skoring Parameter

\begin{tabular}{lcccccc}
\hline \hline $\begin{array}{c}\text { Skor/ } \\
\text { Parameter }\end{array}$ & $\mathbf{1}$ & $\mathbf{2}$ & $\mathbf{3}$ & $\mathbf{4}$ & $\mathbf{5}$ \\
\hline $\begin{array}{l}\text { Curah Hujan } \\
\text { (mm/tahun) }\end{array}$ & $<1500$ & $1500-$ & $2000-$ & $2500-3000$ & $>3000$ \\
Jenis Tanah & $\begin{array}{c}\text { Alluvial, } \\
\text { Glei }\end{array}$ & $\begin{array}{c}\text { Latosol } \\
2000\end{array}$ & $\begin{array}{c}2500 \\
\text { Brown } \\
\text { Foret, }\end{array}$ & $\begin{array}{c}\text { Andosol, } \\
\text { Grumosol, }\end{array}$ & $\begin{array}{c}\text { Regosol, } \\
\text { Litosol, }\end{array}$
\end{tabular}

\begin{tabular}{lccccc}
$\begin{array}{l}\text { Kelerengan } \\
(\%)\end{array}$ & $0-8$ & $8-15$ & $15-25$ & $25-45$ & $>45$ \\
$\begin{array}{l}\text { Tutupan } \\
\text { Lahan }\end{array}$ & $\begin{array}{c}\text { Tubuh } \\
\text { Air }\end{array}$ & Hutan & Kebun & $\begin{array}{c}\text { Tegalan, } \\
\text { sawah, } \\
\text { pemukiman }\end{array}$ & - \\
\hline \hline
\end{tabular}

Reklasifikasi dilakukan hingga menjadi 5 kelas kerawanan longsor, dengan penentuan interval mengacu pada Susanto (2014) [1] menggunakan rumus berikut:

$$
\text { interval } \frac{\text { nilai maksimum - nilai minimum }}{\text { banyak kelas }}
$$

6. Pengolahan Citra Resolusi Tinggi dan Sangat Tinggi Melakukan mosaik dan pansharpening agar citra dapat dilihat dengan jelas. Interpolasi koordinat GCP dan ICP diperlukan untuk dilakukan pengukuran lapangan yang akan dihitung kekuatan jaringnya dengan melakukan perhitungan SoF. Hasil koordinat yang memenuhi standar GCP dan ICP digunakan dalam proses orthorektifikasi dan uji akurasi.

7. Pembuatan Peta Vegetasi

Melakukan perhitungan algoritma Normalized Difference Vegetation Index (NDVI)

8. Pembuatan Peta Kebasahan

Melakukan perhitungan algoritma Normalized Difference Water Index (NDWI).

9. Pengolahan Parameter Groundtruth

Melakukan perbandingan data yang didapatkan dari citra dan didapatkan dari lapangan.

\section{HASIL DAN ANALISIS}

\section{A. Citra Terkoreksi}

Koreksi geometrik dilakukan pada masing-masing citra agar dapat dihasilkan luasan yang sesuai dengan keadaan di lapangan.

a. Landsat 8

Dilakukan koreksi geometrik hingga menghasilkan rmse sebesar $0.005 \mathrm{~m}$ yang kemudian dilanjutkan dengan melakukan koreksi radiometrik dengan metode FLAASH menggunakan perangkat lunak pengolah data citra.

b. SPOT

Citra Satelit SPOT direktifikasi dengan menggunakan perangkat lunak pengolah citra hingga didapatkan rmse sebesar 0,88 m. Hal tersebut menunjukkan bahwa proses rektifikasi yang dilakukan dapat dikatakan memenuhi standar, yakni $\leq 1 \mathrm{~m}$ sesuai dengan yang tertera pada PerkaBIG [1].

c. Quickbird

Citra satelit resolusi tinggi Quickbird digunakan dalam pembuatan peta vegetasi dan peta kebasahan. Dimulai dengan melakukan mosaik dan pansharpening yang dilanjutkan dengan menginterpolasi koordinat citra menjadi titik GCP dan ICP untuk digunakan dalam pengukuran lapangan. Pemilihan lokasi dan sebaran titik GCP dan ICP mengacu pada Modul Validasi Peta Rencana Tata Ruang BIG (2016) [2] dimana penempatan titik tersebut harus dapat diidentifikasi secara jelas pada citra.

Terdapat 8 titik GCP dan 12 titik ICP yang digunakan dalam penelitian ini. Nilai SoF yang didapatkan sebesar 0.2115 sesuai dengan perhitungan berikut. 


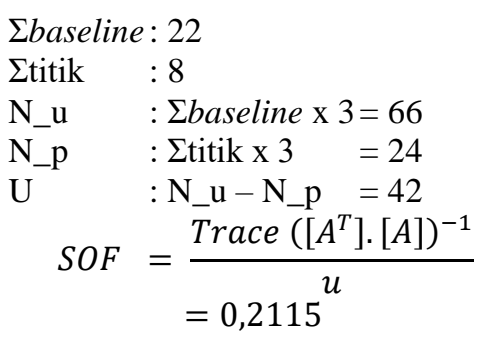

Semakin kecil nilai SOF maka semakin baik konfigurasi jaring, dan begitu pula sebaliknya. Perhitungan SOF yang dilakukan telah menghasilkan nilai $<1$ sehingga desain jaring yang telah dibuat dapat dianggap kuat [3].

Pengambilan data berupa koordinat titik kontrol (GCP) dan titik uji akurasi (ICP) dilakukan dengan menggunakan GPS geodetik dual frekuensi dengan metode statik dalam durasi pengukuran 30-45 menit pada masing-masing titik. Pengolahan data pengukuran dilakukan menggunakan perangkat lunak pengolah data GPS yang meliputi proses post processing dan network adjustment.

Koordinat GCP dan ICP yang didapatkan telah diikatkan dengan CORS ITS S dan telah dikoreksi dengan SRGI BIG hingga didapatkan $\mathrm{dx}=-4.306 \mathrm{~m}$ dan $\mathrm{dy}=0.391 \mathrm{~m}$ untuk selanjutnya digunakan dalam proses orthorektifikasi menggunakan perangkat lunak pengolah citra hingga didapatkan RMSE yang diharuskan $\leq 1,5$ piksel yakni sebesar 0.7875 piksel. Berikut merupakan RMSE dari koordinat yang telah diolah.

Tabel 2. RMSE Citra Quickbird (SRGI)

\begin{tabular}{crlr}
\hline \hline $\begin{array}{c}\text { Nama } \\
\text { Titik }\end{array}$ & RMSE & $\mathbf{X}(\mathbf{m})$ & Y $(\mathbf{m})$ \\
\hline GCP01 & 0.493 & 611415.0625 & 9212055.26 \\
GCP02 & 0.391 & 610493.7655 & 9215153.548 \\
GCP03 & 0.207 & 612407.1645 & 9216339.387 \\
GCP04 & 0.644 & 610388.3905 & 9219113.217 \\
GCP05 & 0.22 & 612762.5285 & 9220378.888 \\
GCP06 & 0.784 & 613208.4405 & 9223709.584 \\
GCP07 & 0.597 & 610415.7845 & 9223937.052 \\
GCP08 & 0.448 & 610728.3145 & 9227575.156 \\
ICP01 & 0.628 & 611176.4635 & 9211689.356 \\
ICP02 & 0.222 & 610453.8785 & 9213282.668 \\
ICP03 & 0.303 & 610779.3935 & 9213638.819 \\
ICP04 & 0.293 & 611867.6925 & 9214775.977 \\
ICP05 & 0.216 & 611103.6175 & 9215903.052 \\
ICP06 & 0.194 & 612664.9875 & 9216831.495 \\
ICP07 & 0.37 & 612078.4525 & 9218234.885 \\
ICP08 & 0.439 & 611217.0885 & 9219342.436 \\
ICP09 & 0.397 & 611224.6875 & 9221431.059 \\
ICP10 & 0.626 & 611717.0115 & 9224112.681 \\
ICP11 & 0.381 & 610678.3295 & 9226189.472 \\
ICP12 & 0.257 & 611768.9875 & 9229012.678 \\
\hline \hline
\end{tabular}

Citra tegak yang dihasilkan dari proses orthorektifikasi selanjutnya dilakukan uji akurasi untuk mengetahui nilai ketelitian citra. Uji akurasi dilakukan dengan menghitung RMSE dari seluruh titik ICP terlebih dahulu kemudian dihitung dengan rumus sesuai dengan Pedoman Teknik Ketelitian Peta Dasar berikut.

Akurasi horisontal $=1,5175 \times$ RMSE

Hasil dari perhitungan uji akurasi didapatkan ketelitian horizontal sebesar 0,9105 sehingga dapat dikatakan memenuhi standar [2] dengan termasuk pada kelas 1 pada skala 1:5000.

\section{B. Korelasi Antar Data Citra}

Penggunaan citra satelit multilevel dalam penelitian ini perlu dilakukan pengujian kekuatan/kesesuaian hubungan antar data citra. Hubungan tersebut didapatkan dengan menerapkan algoritma NDVI pada Landsat dan Quickbird, serta penggunaan band Blue dan Red pada SPOT dan Foto.

Tabel 3.

NDVI pada citra

\begin{tabular}{ccccc}
\hline Nama & \multicolumn{4}{c}{ NDVI } \\
\cline { 2 - 5 } Titik & Foto & SPOT & Landsat & Quickbird \\
\hline GT-01 & 0.04 & 0.026 & 0.28 & 0.4 \\
GT-02 & 0.063 & 0.3 & 0.4 & 0.51 \\
GT-03 & 0.056 & 0.06 & 0.29 & 0.62 \\
GT-04 & 0.028 & 0.06 & 0.25 & 0.26 \\
GT-05 & 0.03 & 0.26 & 0.46 & 0.28 \\
\hline \hline
\end{tabular}

Berikut merupakan ilustrasi yang menunjukkan hubungan antar data terhadap citra yang diperoleh dari pemrosesan NDVI terhadap masing-masing citra dengan pendekatan panjang gelombang pada citra foto dan SPOT.

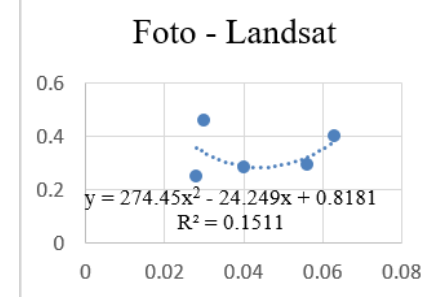

(a )

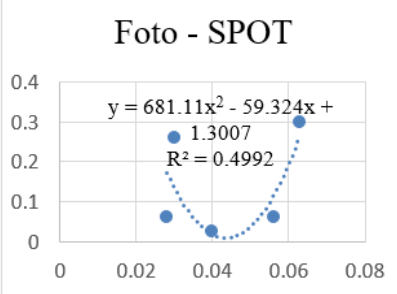

(b)

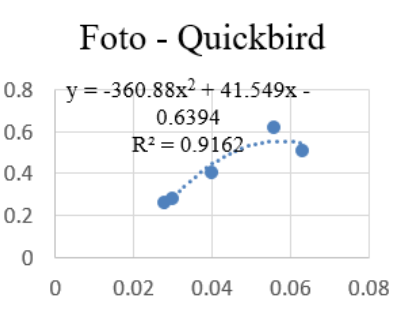

(c)

Gambar 2. (a) Korelasi Citra Foto dengan Landsat (b) Korelasi Citra Foto dengan Citra SPOT (c) Korelasi Citra Foto dengan Citra Quickbird.

Dari gambar 2 dapat diketahui bahwa korelasi terendah hingga terkuat berturut-turut adalah foto dengan Landsat sebesar 0,0945, foto dengan SPOT sebesar 0,2677, serta foto dengan Quickbird sebesar 0,912. Hal tersebut dimungkinkan karena resolusi spasial yang dimiliki masing-masing citra. Citra Quickbird memiliki resolusi sangat tinggi yakni sebesar $0,6 \mathrm{~m}$ sehingga memiliki hubungan yang lebih kuat dengan foto jika dibandingkan dengan SPOT sebesar $1,5 \mathrm{~m}$ dan Landsat sebesar $30 \mathrm{~m}$. Oleh karena itu, dalam penelitian ini parameter groundtruth diolah dengan menitikberatkan pada penggunaan citra Quickbird.

\section{Peta Curah Hujan}

Data curah hujan didapatkan dalam bentuk tabular mencakup 26 stasiun curah hujan yang tersebar di Kabupaten Tuban. Klasifikasi dilakukan dengan mengacu pada Puslitbangtanak (2002) dalam Isti (2013) [4].

\section{D.Peta Jenis Tanah}

Data jenis tanah didapatkan dalam format shapefile (vektor) yang mencakup seluruh kecamatan pada Kabupaten Tuban. Klasifikasi dilakukan dengan mengacu pada Sugianti (2014) [5].

\section{E. Peta Kelerengan}

Data kemiringan lereng didapatkan dalam format shapefile (vektor) dimana penentuan klasifikasi dilakukan dengan mengacu pada Sugianti (2014) [5]. 


\section{F. Peta Tutupan Lahan}

Tutupan lahan diperoleh dari citra Landsat 8 yang diolah dengan melakukan koreksi radiometrik terlebih dahulu. Dilanjutkan dengan interpretasi digital dengan metode Supervised Classification: Maximum Likelihood dengan matriks konfusi sebesar 80,19\%. Proses klasifikasi dilakukan dengan mengacu pada Kesaulya, 2014 (mengacu pada Permen PU No.22 tahun 2007 dan Nugroho Jefri,2009) [6]. Luas masing-masing kelas yang didapatkan ditunjukkan pada tabel berikut.

Tabel 4.

Luas Tutupan Lahan

\begin{tabular}{|c|c|c|}
\hline Tutupan Lahan & Luas (ha) & $\%$ \\
\hline Tubuh Air & 507.7 & 0.26 \\
\hline Hutan & 70257.6 & 35.52 \\
\hline Kebun & 4325.6 & 2.19 \\
\hline Tegalan, sawah, pemukiman & 122688.0 & 62.03 \\
\hline
\end{tabular}

\section{G.Peta Kerawanan Longsor}

Dalam penelitian ini digunakan metode Storie yang membutuhkan data curah hujan, jenis tanah, kemiringan lereng, dan tutupan lahan dalam penyusunannya, dimana penentuan parameter tersebut mengacu pada Pedoman Penyusunan Penataan Ruang Kawasan Rawan Bencana Longsor Kementerian Pekerjaan Umum No.22/PRT/M/2007 [7].

Data yang diberikan skor seperti pada tabel 1 kemudian di-overlay dan diterapkan tools intersect untuk dilajutkan pada proses skoring dan klasifikasi ulang sesuai dengan interval yang ditentukan dengan mengacu pada Susanto (2014) [1] seperti rumus berikut.

interval $=\frac{\text { nilai maksimum }- \text { nilai minimum }}{\text { banyak kelas }}$

Dari perhitungan interval tersebut didapatkan rentang nilai masing-masing kelas sepanjang 2,2 hingga didapatkan hasil klasifikasi dalam 5 kelas seperti berikut.
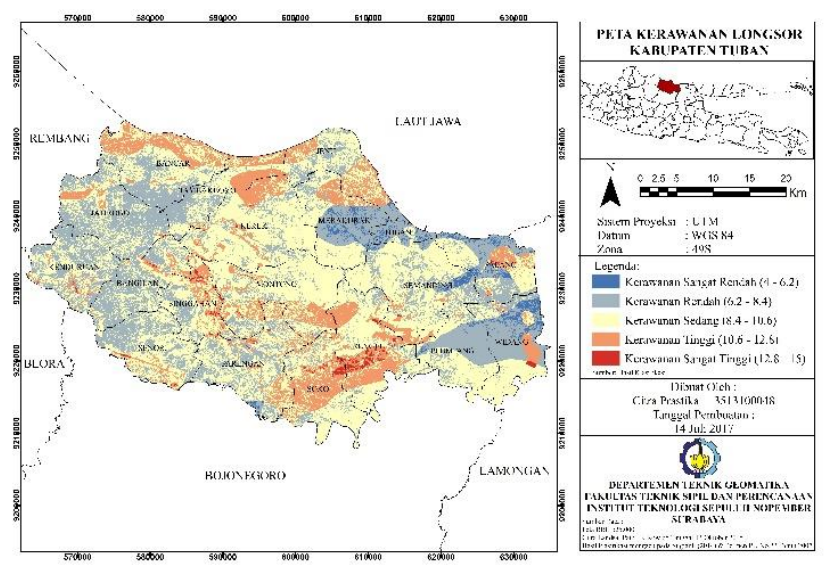

Gambar 3. Peta Kerawanan Longsor.

Dari hasil klasifikasi yang telah dilakukan didapatkan luas masing-masing kelas kerawanan longsor seperti tabel berikut.

Tabel 8.

Luas Kerawanan Longsor

\begin{tabular}{lrr}
\hline \hline Kategori & Luas (ha) & \multicolumn{1}{c}{$\%$} \\
\hline Kerawanan Sangat Rendah & $3.835,920$ & 1.9 \\
Kerawanan Rendah & $62.136,500$ & 31.5 \\
Kerawanan Sedang & $99.519,900$ & 50.5 \\
Kerawanan Tinggi & $31.218,300$ & 15.8 \\
Kerawanan Sangat Tinggi & 268,537 & 0.1 \\
\hline \hline
\end{tabular}

\section{H.Korelasi antar Parameter Kerawanan Longsor}

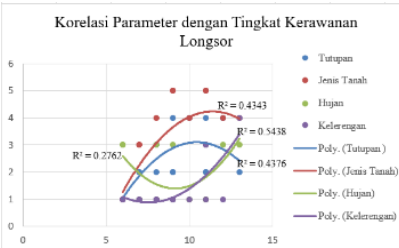

Gambar 4. Korelasi Parameter dengan Tingkat Kerawanan Longsor.

Dari gambar 13 dapat diketahui bahwa besar korelasi parameter longsor dengan tingkat kerawanan longsor dari rendah ke tinggi berturut-turut adalah curah hujan sebesar 0.06, tutupan lahan sebesar 0.49 , jenis tanah sebesar 0.59 , serta kelerengan sebesar 0.63 .

\section{Groundtruth}

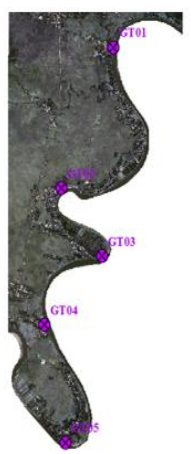

Gambar 5. 5 titik groundtruth diletakkan pada tiap-tiap myander di tepian Sungai Bengawan Solo.

Sejumlah 5 titik groundtruth diletakkan pada tiap-tiap myander di tepian Sungai Bengawan Solo. Pengambilan sample tanah (untuk pengujian kadar air dan tekstur tanah) dilakukan pada bagian disturb land (tanah terganggu/permukaan tanah) dengan menggunakan pipa paralon yang ditancapkan sedalam $\pm 30 \mathrm{~cm}$ pada tanah yang diambil sekitar $1 \mathrm{~kg}$ agar dapat dilakukan pengujian pada sample tanah.

Pengambilan citra foto dilakukan dengan menggunakan Phantom 3 Advance yang diterbangkan sekitar 150m diatas titik groundtruth.

Jika disesuaikan dengan hasil klasifikasi hingga terbentuk peta kerawanan longsor seperti pada gambar 4 titik groundtruth berada pada tingkat kerawanan yang dapat dilihat pada tabel berikut.

$$
\text { Tabel } 9 .
$$

Klasifikasi kerawanan titik groundtruth

\begin{tabular}{cl}
\hline \hline Nama Titik & \multicolumn{1}{c}{ Klasifikasi Kerawanan } \\
\hline GT-01 & Kerawanan Tinggi \\
GT-02 & Kerawanan Sedang \\
GT-03 & Kerawanan Sangat Rendah \\
GT-04 & Kerawanan Sangat Rendah \\
GT-05 & Kerawanan Sedang \\
\hline \hline
\end{tabular}

\section{J. NDVI dan NDWI (Quickbird)}

Citra tegak yang telah dihasilkan kemudian diproses dengan algoritma NDVI untuk diketahui tingkat kehijauannya. Dihasilkan 5 kelas sesuai dengan Peraturan Menteri Kehutanan Republik Indonesia No.P.12/MenhutII/2012 [8]hingga menghasilkan peta seperti berikut. 


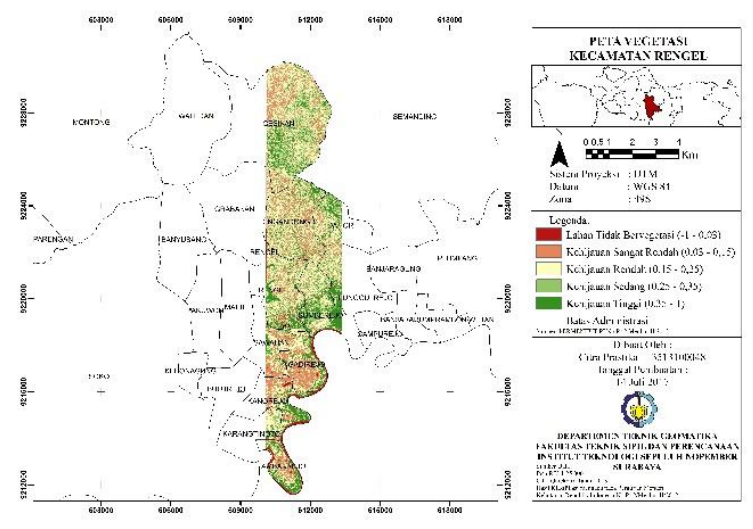

Gambar 6. Peta Vegetasi.

Citra tegak yang dihasilkan selanjutnya juga diproses dengan algoritma NDWI. Proses klasifikasi dilakukan dengan mengacu pada Xu (2006, merujuk ke MNDWI) [9] hingga dihasilkan seperti berikut.
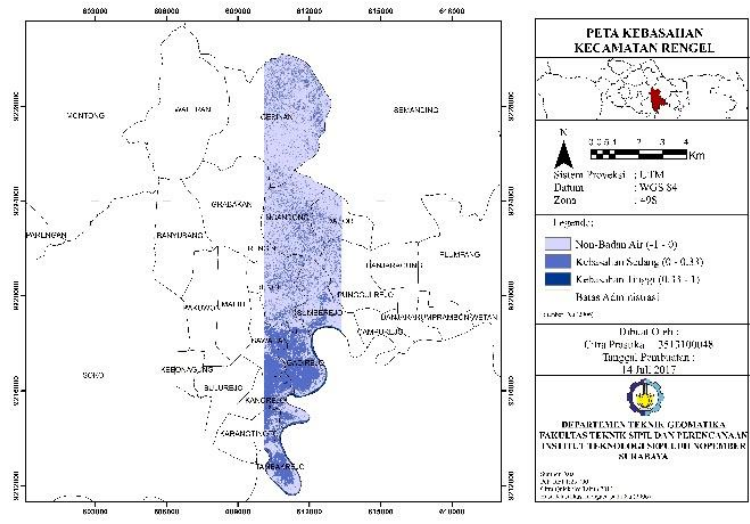

Gambar 7. Peta Kebasahan

\section{K. Uji Laboratorium}

Pengujian kadar air dalam tanah dilakukan pada Laboratorium Dinas Lingkungan Hidup Kabupaten Tuban. Pengujian tekstur tanah dilakukan pada Laboratorium Mekanika Tanah dan Batuan Teknik Sipil - ITS dengan menggunakan metode ayakan dan hydrometer yang mengacu pada Pedoman Penyelidikan dan Pengujian Tanah Dasar untuk Pekerjaan Jalan Departemen Pekerjaan Umum No.003-03/BM/2006 [10]. Pengujian tanah tersebut dilakukan berdasarkan analisis ukuran butir untuk mengetahui fraksi penyusun tanah.

Hasil pengujian kadar air dan tekstur tanah yang telah digabungkan dengan nilai NDVI dan NDWI melalui pengolahan citra Quickbird pada masing- masing titik groundtruth dapat dilihat pada tabel berikut.

Tabel 10.

Hasil parameter groundtruth

\begin{tabular}{ccccccc}
\hline \hline Nama & \multirow{2}{*}{ Nitik } & \multirow{2}{*}{ NDWI } & \multirow{2}{*}{ NDVI } & \multirow{2}{*}{ Kadar } & \multicolumn{3}{c}{ Tekstur Tanah } \\
\cline { 5 - 7 } & & & Air & Sand & Silt & Clay \\
\hline GT-01 & 0.12 & 0.27 & 75.22 & 80.2 & 13.9 & 5.9 \\
GT-02 & 0.07 & 0.20 & 57.17 & 71.1 & 11.2 & 17.6 \\
GT-03 & 0.10 & 0.45 & 42.55 & 79.4 & 14.2 & 6.4 \\
GT-04 & 0.07 & 0.27 & 37.17 & 81.9 & 12.2 & 5.9 \\
GT-05 & 0.09 & 0.56 & 37.67 & 70.7 & 15.2 & 14.1 \\
\hline \hline
\end{tabular}

Tekstur tanah menunjukkan komposisi tanah penyusun yang dinyatakan sebagai perbandingan proporsi $(\%)$ relatif antara fraksi pasir (sand) berdiameter 2,00-0,20 mm, debu (silt) berdiameter $0,20-0,002 \mathrm{~mm}$ dan liat (clay) $(<2$ mikrometer). Pengambilan sampel tanah berada pada bagian disturb land (sekitar $20 \mathrm{~cm}$ dari permukaan tanah ke bagian dalam) sehingga terdapat beberapa material yang sangat jelas berbeda ukuran dengan pasir (secara kasat mata) seperti batu/kerikil, keong, akar tanaman, dan sebagainya. Dalam pengujian tanah material tersebut ikut terhitung dalam kategori $>2,00 \mathrm{~mm}$.

\section{Korelasi Parameter Groundtruth}
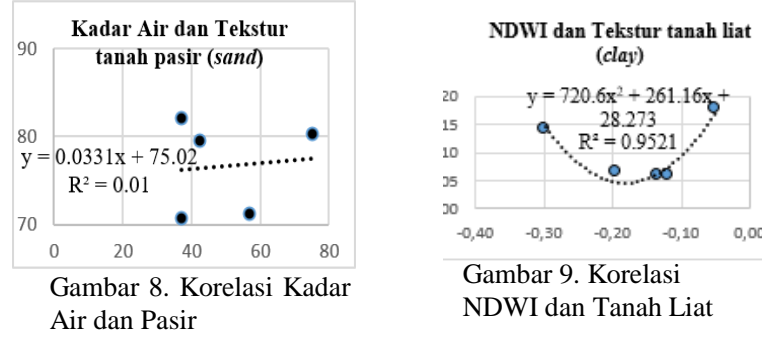

Dominasi fraksi pasir akan menyebabkan terbentuknya sedikit pori-pori makro, sehingga daya pegang terhadap air sangat lemah. Kondisi ini menyebabkan air mudah masukkeluar tanah dan hanya sedikit yang tertahan [11], hal tersebut dibuktikan dengan didapatkannya korelasi sebesar 0.1 terhadap kadar air dan pasir.

Dominasi fraksi liat akan menyebabkan terbentuknya banyak pori-pori mikro, sehingga daya pegang terhadap air sangat kuat. Kondisi ini menyebabkan air yang ke masuk segera terperangkap, dibuktikan dengan didapatkannya $\mathrm{R}^{2}$ sebesar 0,95 terhadap air (NDWI) dan tanah liat.

Dominasi fraksi debu akan menyebabkan terbentuknya pori-pori meso dalam jumlah sedang, sehingga menghasilkan daya pegang terhadap air yang cukup kuat. Hal ini menyebabkan air dan udara cukup mudah masukkeluar tanah, sebagian air akan tertahan. Tanah bertekstur debu umumnya lebih subur dibandingkan dengan tanah bertekstur pasir [11].

Selain tekstur tanah dan kadar air dalam tanah, vegetasi juga berperan penting dalam mengendalikan stabilitas tanah. Keberadaan pohon di sepanjang tebing sangat mempengaruhi stabilitas tebing melalui fungsi perakaran yang melindungi tanah sehingga mempengaruhi ketahanan geser (shear strength) tanah. Adanya bahan organik pada tanah akan mempengaruhi peningkatan kemampuan menahan air, pelarutan sejumlah hara dari mineral, serta meningkatnya kegiatan dekomposi bahan organik. Hal tersebut didukung dengan didapatkannya $\mathrm{R}^{2}$ sebesar 0,95 terhadap vegetasi (NDVI) dan air (NDWI).

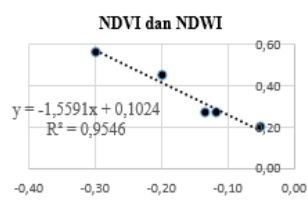

Gambar 10. Korelasi.

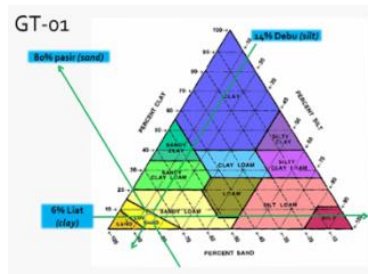

Gambar 12. Tekstur Tanah Menurut Segitiga USDA
Jika dilihat dari sifat fisik tanah (tekstur tanah dan kadar air) serta adanya vegetasi pada titik groundtruth, GT-01 memiliki potensi yang begitu besar (dibandingkan dengan titik groundtruth lain) untuk terjadi suatu longsoran. Dengan kandungan fraksi pasir $80,2 \%$, debu $13,9 \%$, dan liat 5,9\%, 
mengacu pada USDA (1999) [12], tanah pada GT-01 memiliki kategori pasir berlempung.

Dengan nilai NDWI sebesar 0,12 yang mengartikan bahwa terdapat kandungan air dalam GT-01 sehingga dimungkinan adanya suatu vegetasi yang tumbuh pada titik tersebut yang juga diperkuat dengan nilai NDVI sebesar 0.27. Kadar air dalam GT-01 memiliki kategori yang cukup tinggi yakni $75,22 \%$ yang mana hal tersebut merupakan pemicu terjadinya longsoran. Jika terjadi peningkatan kandungan air dalam tanah (seperti meresapnya air hujan, air sungai yang meluap, air sawah/kolam yang bocor), akan terjadi akumulasi air yang semakin merenggangkan ikatan antar butir tanah yang pada akhirnya akan mendorong butirbutir tanah untuk longsor. Berikut merupakan data terkait parameter yang telah didapatkan.

Tabel 11.

Parameter Groundtruth

\begin{tabular}{|c|c|c|c|c|c|c|c|c|}
\hline \multirow[b]{2}{*}{$\begin{array}{l}\text { Nama } \\
\text { Titik }\end{array}$} & \multirow[b]{2}{*}{ NDWI } & \multirow[b]{2}{*}{ NDVI } & \multirow[b]{2}{*}{$\begin{array}{c}\text { Kadar } \\
\text { Air }\end{array}$} & \multicolumn{4}{|c|}{ Tekstur Tanah } & \multirow[b]{2}{*}{ Klasifikasi Kerawanan } \\
\hline & & & & $\begin{array}{c}\text { Sand } \\
\text { (pasir) }\end{array}$ & $\begin{array}{c}\text { Silt } \\
\text { (debu) }\end{array}$ & $\begin{array}{l}\text { Clay } \\
\text { (liat) }\end{array}$ & Kategori (USDA) & \\
\hline GT-01 & 0.12 & 0.27 & 75.22 & 80.2 & 13.9 & 5.9 & Pasir berlempung & Kerawanan Tinggi \\
\hline GT-02 & 0.07 & 0.20 & 57.17 & 71.1 & 11.2 & 17.6 & Lempung berpasir & Kerawanan Sedang \\
\hline GT-03 & 0.10 & 0.45 & 42.55 & 79.4 & 14.2 & 6.4 & Pasir berlempung & Kerawanan Sangat Rendah \\
\hline GT-04 & 0.07 & 0.27 & 37.17 & 81.9 & 12.2 & 5.9 & Pasir berlempung & Kerawanan Sangat Rendah \\
\hline GT-05 & 0.09 & 0.56 & 37.67 & 70.7 & 15.2 & 14.1 & Lempung berpasir & Kerawanan Sedang \\
\hline
\end{tabular}

\section{KESIMPULAN}

Berdasarkan pengolahan dan analisis data yang telah dilakukan, berikut adalah kesimpulan yang penulis dapatkan dalam penyelesaian studi ini.

1. Didapatkan 5 kelas kerawanan longsor yakni sangat rendah, rendah, sedang, tinggi, dan sangat tinggi. Kerawanan sangat rendah dengan 1,9\% dari luas total wilayah Tuban, kerawanan rendah dengan $31,5 \%$, kerawanan sedang dengan luas sebesar 50,5\%, kerawanan tinggi dengan $15,8 \%$, dan kerawanan sangat tinggi dengan $0,1 \%$.

2. Kabupaten Tuban didominasi oleh tingkat kerawanan sedang dengan luas 99.519,9 ha, sedangkan untuk tingkat kerawanan sangat tinggi hanya seluas 268,537 ha pada sebagian Kecamatan Kenduruan, Kecamatan Bangilan, Kecamatan Singgahan, Kecamatan Senori, Kecamatan Kerek, Kecamatan Jatirogo, Kecamatan Soko, Kecamatan Rengel, Kecamatan Widang, Kecamatan Palang, dan Kecamatan Semanding.

3. Dari ke-5 titik groundtruth yang diteliti, titik GT-01 memiliki kerawanan longsor yang lebih tinggi dibandingkan dengan titik groundtruth yang lain. GT-01 berada pada tingkat kerawanan sedang dimana titik ini berada 1-2 tingkat lebih tinggi dibandingkan GT-02, GT03, GT-04, dan GT-05.

\section{DAFTAR PUSTAKA}

[1] Peraturan Kepala Badan Informasi Geospasial, Pedoman Teknis Ketelitian Peta Dasar. Bogor, 2014.

[2] Badan Informasi Geospasial, Modul Validasi Peta Rencana Tata Ruang. Jakarta, 2016.

[3] Z. A. Abidin, Penentuan Posisi Dengan Receiver GPS Satu Frekuensi, Status Dan Permasalahannya. Bandung: Depertemen Teknik Geodesi, 2005.

[4] A. Y. Isti, "Pemetaan Zonasi Kerentanan Banjir di Kabupaten Sragen Menggunakan Teknologi Penginderaan Jauh dan Sistem Informasi Geografis. Penginderaan Jauh dan SIG Sekolah Vokasi Universitas Gajah Mada," 2013.

[5] K. Mulyadi, Dedi; Sarah, Dwi; Sugianti, "Pengkelasan Tingkat Kerentanan Gerakan Tanah Daerah Sumedang Selatan Menggunakan Metode Strokie," 2014.

[6] dkk Kesaulya Hertine, "Perencanaan Mitigasi Bencanan Longsor di Kota Ambon. Jurnal Perencanaan Wilayah \& Kota Universitas
Dinas Pekerjaan Umum, Peraturan Menteri Pekerjaan Umum Tentang Pedoman Penataan Ruang Kawasan Rawan Bencana Longsor. Jakarta, 2007.

[8] A. D. Susanto, "Analisis Tingkat Rawan Kekeringan Lahan Sawah Dengan Pemanfaatan Penginderaan Jauh dan Sistem Informasi Geografis di Kabupaten Sragen," Universitas Muhammadiyah Surakarta, 2014.

[9] Menteri Kehutanan, Peraturan Menteri Kehutanan Tentang Perubahan Kedua Atas Peraturan Menteri Kehutanan Nomor P.32/Menhut-Ii/2009 Tentang Tata Cara Penyusunan Rencana Teknik. Jakarta: Rehabilitasi Hutan dan Lahan Daerah Aliran Sungai (Rtk RHL-DAS), 2012.

[10] Departemen Pekerjaan Umum, Pedoman Penyelidikan dan Pengujian Tanah Dasar untuk Pekerjaan Jalan Departemen Pekerjaan Umum. Jakarta, 2006.

[11] K. Ali Hanafiah, Dasar-dasar Ilmu Tanah. Jakarta: Rajagrafindo Persada, 2005.

[12] USDA. Second Edition, Soil Taxonomy: A Basic System of Soil Classification for Making and Interpreting Soil Surveys. U.S. Government Printing Office Washington, DC, 1999. 